\title{
Socio-Economic Status of Farmers in Raisen District of Madhya Pradesh: A Case Study
}

\author{
Ram Kumar $^{1 *}$, Ashish Kumar ${ }^{2}$, Vinod Prajapat ${ }^{2}$ and Vishal Panwar ${ }^{2}$ \\ ${ }^{1}$ Department of Plant Protection of Chaudhry Charan Singh University (CCSU), \\ Meerut Uttar Pradesh - 250001, India \\ ${ }^{2}$ Amity institute of Organic Agriculture of Amity University, Noida \\ Uttar Pradesh - 201301, India
}

*Corresponding author

\begin{abstract}
A B S T R A C T
Key w ords

Socio-economic status, Farmers, Madhya Pradesh

Article Info

Accepted:

22 October 2018

Available Online:

10 November 2018

The present study describes the Socio-economic Status of Farmers in Raisen district, Madhya Pradesh, India. The study area was Badi Blocks of the Raisen district. The information was collected on the source of a personal interview to each of the farmers through a questionnaire. A total sample of 800 farmers was selected randomly from 15 different villages of Badi block during 2017. The study revealed that they are very prosperous and progressive farmers with moderate literacy $75 \%$ and knowledge about agricultural methods, including Integrated Pest management $12 \%$ and they adopt rice cropping system which includes Wheat, Gram and Tomato with awareness about their improved management practices. By introducing facilities of modern technology, their socioeconomic standard can be further increased.
\end{abstract}

\section{Introduction}

Many low-income countries in south Asia, have suffered major natural disasters and political upheavals through since 1990s. These events remind observers about what is hidden in official poverty statistics: that the condition of poverty is linked closely to vulnerability. Raisen is the administrative headquarter of Raisen district of Madhya Pradesh, India which is located in the west part adjacent to Sehore district, Vidisha district in the north, Sagar district in the east and south-east, Narsimhapur district in the south-east. The district has a humid subtropical climate with summer, winter and monsoon forming the seasonal cycle. The major crops grown in the district are Rice, Wheat, Gram and Tomato. In accordance with census 2014, the district has a total population of $1,331,699$. It covers an area of 8,395 square kilometers $(3,241 \mathrm{sq} \mathrm{mi})$. The Literacy rate of the district is 74.26 percent (Ann., 2014). https://www. mapsofindia.com/maps/madhyapradesh/distric ts/raisen.htm

The farmers are socio-economically well off as compared to the non-farmers, community. As for education, nearly by two-thirds in the northern region were literate. Across farm size, large-scale farm household heads are better educated than small-scale household 
heads. The literacy ratio was higher in maleheaded households compared to femaleheaded households in Badi regions (Sharma et al., 2003). They differ widely among themselves in respect of the regions they live in, languages they speak, physical features they display, the geographical terrain they inhabit, modes in which they make their living, levels of development at which they are placed and size of community they represent.

Agriculture is the primary source of livelihood for the overwhelming majority of the population in the district. Majority of the population are engaged in agricultural and livestock rearing activities.

Data pertaining to the contribution of various economic activities among the farmers is mandatory for any economic development programs for the farmers. Though various studies on socio-economic conditions of farmers were carried out in India, studies are limited with reference to the Badi farmers, Raisen district of Madhya Pradesh. Their lands are irrigated, alienated and have canal and tube well for irrigation facilities. They are utilizing chemical fertilizers, improved seeds, pesticides etc. in their lands. Area of Badi is therefore somewhat different from other areas mainly on account of the difference in natural topography surrounded by hills and forest. And also the typical topography of undulating and hilly areas has made area agriculture profitable.

The present study reveals the socio-economic status of the Badi farmers of the district with the following objectives:

To appraise the socio-economic condition of Badi farmers in Raisen district of Madhya Pradesh, India.

To study the existing cropping and resource use patterns to locate the specific socio- economic weaknesses in their production organization.

To find the social constraints that inhibit the adoption of new technology.

\section{Materials and Methods}

The study was conducted with a sample of 800 farmers of 15 different villages of Raisen district of Madhya Pradesh. A multistage purposive cum random sampling design was followed for selection of the respondents. The investigation was carried out with various problems faced by the farmers in the Badi block in Raisen district.

The people in this area are mainly agrarian, engaged in farming. Most of the inhabitants are involved in Agriculture. Some of the food crops grown around the area are rice, wheat, gram, and vegetables, most of which come from the major agricultural areas in the area. Livestock production is also practiced but mainly on extensive system of production.

Data collection: Data from this study were obtained from only primary source. The primary data include the use of questionnaire and oral interview, which were duly administered to the rural farmers. These questionnaires were administered in person due to the little or no formal education of the farmers. The questionnaire schedule provided information on socio-economic characteristics of rural farmers. Data were also collected on the various sources of Madhya Pradesh planning commission to agricultural, social and economic risks.

Data analysis: To describe the socioeconomic characteristics of rural farmers and identify various problems associated with measures in this area, analytical tools that were used are mainly descriptive statistics such as mean, frequency, pie charts, percentages, tables and 
other applicable tools as indicated by responses to the respective survey questions.

The data were collected by personal interview method using both structural schedule and semi-structured interview during 2017 by supplying the questionnaire mentioning the following salient points.

Population of the village

Family Structure

Educational Status of Family Members

Housing Conditions

Electricity Facility

Source of Water

Mode of Transportation

Occupational Pattern

Land Holdings

Source of Irrigation

Farm Mechanization

Livestock

Difficulties in Agriculture Improvement

Priorities for Future Investment

Source of Agricultural Information

Sources of Credit Supply

Cropping Pattern

Plant Protection

Dynamics of Crop Production

Marketing System of Agricultural Produce

Marketed Surplus of Farm Produce

Returns from Agricultural Produces

Literacy rate $(\%)$

Cropping Pattern

Soil type

Av. Pesticide used (/ha)

Knowledge about IPM

After completion of the survey, a total of 800 filled in the questionnaire were received and were analyzed to find out the socio-economic condition of the farmers in the blocks.

\section{Results and Discussion}

Age distribution of the farmers: The higher the age of the respondents the higher their experience in farming (all things being equal) and this translates to more encounter with risks among older farmers than in younger farmers. The age distribution of the rural farmers interviewed in the course of this research work is stated below (See Table 1).

In the present study, it was observed that the farmers are socio-economically progressive in the area. Agriculture is the primary source of livelihood for the overwhelming majority of the farmers. So as to eradicate the problems of farmers, it is necessary for the policymakers to identify and quantify the socio-economic factors which are inhibiting their growth and development. The farmers owing to their lifestyle and community habits and habitats have not been able to keep pace with the modern society. Farmers are not as innovative as the people of rest of India. The baseline information gathered as part of study is included in Table 2.

They may choose to diversify their crops, store grain, engage in livestock and poultry, favour traditional techniques over modern technology and enter into share-cropping arrangements. From the investigation, it was observed that the average populations of Badi blocks are 790 and 890, respectively. The majority of the farm families were nuclear in the blocks. As per the education status of the villagers, the illiterate percentage was observed $68 \%$ in the block. The major occupation of the farmers was agriculture and livestock rearing. Majority of the land holdings are landless 9.21\%, Marginal $21.09 \%$ and Small $67.10 \%$ in the block. The cropping pattern of the studied area includes Rabi and Kharif crops are respectively Wheat/Tomato and Rice in the block. More than 85 percent households are electrified in the block. The sources of irrigation available in the blocks were canal and tube wells etc. Likewise, the livestock population in the blocks is cow, goat and poultry on the block. 
Table.1 Age distribution of the respondents

\begin{tabular}{|l|l|l|}
\hline AGE DISTRIBUTION & FREQUENCY & PERCENTAGE \\
\hline LESS THAN 30 & 180 & 22.50 \\
\hline 30-40 & 245 & 30.62 \\
\hline $40-50$ & 210 & 26.25 \\
\hline ABOVE 50 & 165 & 20.62 \\
\hline TOTAL & 800 & 100 \\
\hline
\end{tabular}

Source: Field survey, 2017

Table.2 Baseline information at Badi block of Raisen District of Madhya Pradesh

\begin{tabular}{|c|c|c|}
\hline Sr.no. & Component & Results \\
\hline 1. & Average Population of the village & 767 \\
\hline 2. & Electricity Facility & $\begin{array}{l}\text { Electrified } 85.05 \% \\
\text { Unelectrified } 14.95 \%\end{array}$ \\
\hline 3. & Source of Water & $\begin{array}{l}\text { Tube Well } 18.05 \% \\
\text { Hand pump } 61.11 \% \\
\text { Pond } 4.16 \% \\
\text { River } 16.68 \%\end{array}$ \\
\hline 4. & Mode of Transportation & $\begin{array}{l}\text { Two-wheeler, Four Wheeler and } \\
\text { Public transport }\end{array}$ \\
\hline 5. & Major Land Holdings & $\begin{array}{l}\text { Landless } 9.21 \% \\
\text { Marginal } 23.69 \% \\
\text { Small } 67.10 \%\end{array}$ \\
\hline 6. & Source of Irrigation & $\begin{array}{l}\text { Canal } 78.27 \% \\
\text { Tubewell } 17.67 \% \\
\text { Other } 4.06 \%\end{array}$ \\
\hline 7. & Farm Mechanization & $\begin{array}{l}\text { Tractor } 29 \% \\
\text { Pump set } 8 \% \\
\text { Sprayer } 56 \% \\
\text { Others } 7 \%\end{array}$ \\
\hline 8. & Livestock & Cow, Goat and Poultry \\
\hline 9. & Difficulties in Agriculture Improvement & $\begin{array}{l}\text { Irrigation } 10 \% \\
\text { Credit 30\% } \\
\text { Transport 7\% } \\
\text { Agriculture Knowledge 25\% } \\
\text { Labour 28\% }\end{array}$ \\
\hline 10. & Source of Agricultural Information & $\begin{array}{l}\text { Extension staff by Daawat (LT } \\
\text { Foods), Mass Media and KVKs }\end{array}$ \\
\hline 11. & $\begin{array}{l}\text { Variety of crop } \\
\text { A. Rice } \\
\text { B. Wheat } \\
\text { C. Gram }\end{array}$ & $\begin{array}{l}\text { Pusa Basmati (PB)-1, PB-21 } \\
\text { GW-273, GW 322,GW-366 } \\
\text { PU30, IPU94, JG 130 }\end{array}$ \\
\hline 12. & Marketing System of Agricultural Produce & $\begin{array}{l}\text { Daawat (LT Foods) } \\
\text { Local traders }\end{array}$ \\
\hline 13. & Sources of Credit Supply & Banks \\
\hline 14. & Soil type & Black soil \\
\hline 15. & Average Pesticide used (/ha) & Very often \\
\hline 16. & Knowledge about IPM & $12 \%$ \\
\hline
\end{tabular}

Source: Field survey, 2017 
The major source of agricultural information in the studied area was Daawat (LT Foods), mass media and relatives. The banks were a major source of credit supply in the area. Use of plant protection measures to save the crops from pests and diseases was observed higher in the blocks.

\section{Suggestions}

Policy suggestions based on the findings from field study of farmers are presented for consideration:

Educational facilities should be provided for the people.

Positive steps should be taken to check the exploitation of the farmer.

Good, reliable transport and communication facilities should be provided.

Multiple cropping and intercropping should be actively encouraged. The government must make major moves to create permanent assets with farmers and provide infrastructural support for meeting input, credit and marketing needs.

Extension agencies must visit the villages and interact with farmers.

Training should be provided to the farmer in different income generating activities.

Suitable steps should be taken by the Government so as to educate the farmers about the importance of crop loan and crop insurance facility.

The role of middle man should be minimized for more benefit to the farmers.

Hence concluded that if all suggestions mentioned above are implemented in the Badi villages, the development of those backward areas can be seen in near future. By introducing facilities of modern technology, their socioeconomic standard can be increased. Thus this weaker part of the society can be turned into the huge mass of human resource. However, further studies are required to know more about them.

\section{References}

Agricultural Statistics at a Glance (2010), Agriculture Census Division, Dept. of Agriculture and Cooperation, Ministry of Agriculture, Govt. of India, New Delhi.

Anonymous (2016-17). Economic survey of Madhya Pradesh, Directorate of Economics and Statistics, Madhya Pradesh Planning and development department, Govt. ofMadhya Pradesh. pp.46.

https://www.mapsofindia.com/maps/madhyap radesh/districts/raisen.htm

State Planning commission report of State Planning commission of Madhya Pradesh pp 24.

Winick, C., 1956. Dictionary of Anthropology, Philosophical Library, New York, P. 546.

\section{How to cite this article:}

Ram Kumar, Ashish Kumar, Vinod Prajapat and Vishal Panwar. 2018. Socio-Economic Status of Farmers in Raisen District of Madhya Pradesh: A Case Study. Int.J.Curr.Microbiol.App.Sci. 7(11): 2802-2806. doi: https://doi.org/10.20546/ijcmas.2018.711.322 